\title{
DC-DC コンバータ用高周波変圧器の実機における装荷統計
}

\section{電力変換器}

\section{○村田 真悟*枡川 重男*}

\section{*東京電機大学}

\section{1. まえがき}

現在，地球温暖化や石油資源の枯渇などの問題から，再 生可能エネルギーを利用した発電や EV, HEV が普及拡大し ている。パワーコンディショナーや EV, HEV 用急速充電器 に用いられる DC-DC コンバータは, 電気的絶縁や小型軽量 化のために高周波変圧器が用いられる。一般的に高周波変 圧器設計に関しては, シミュレーションや電磁界解析を基 にしてメーカーのノウハウを組み込み設計されている。ま た, 設計した変圧器に対してカットアンドトライを行うこ とで特性の改善をしている。しかしながら，高周波，デュ ーティー比可変方形波電圧に対応した変圧器に対しては, 理論的解釈が明らかにされていない。そこで本稿では，商 用周波数変圧器設計の代表的な方法である竹内氏の微増加 比例法[1]を用いて高周波変圧器の実機における電気装荷 $\boldsymbol{A}$, 磁気装荷 $\phi$ 装荷統計を行ったので以下に報告する。

\section{2. 高周波変圧器における微増加比例法}

微増加比例法の基本式は次式で与えられる。

$$
\begin{aligned}
& \frac{K_{0} A \delta \phi}{K_{0} \phi \delta A}=\gamma \ldots \ldots \ldots(1) \\
& \frac{S}{\boldsymbol{f}}=\frac{K_{0} \boldsymbol{A} \phi}{\sqrt{D}} \cdots \ldots \ldots
\end{aligned}
$$

ここで $K_{0}$ は波形率， $\gamma$ は装荷分配定数，A は電気装荷, $\phi$ は磁気装荷, $S / \boldsymbol{f}$ は比容量, $\boldsymbol{f}$ は $10[\mathrm{kHz}]$ で正規化された周 波数, D はデューティー比である。(1), (2)式より以下に示 寸電気装荷 $\boldsymbol{A}$, 磁気装荷 $\boldsymbol{\phi}$ が得られる。

$$
\begin{aligned}
& \boldsymbol{A}=\boldsymbol{A}_{0}\left(\frac{S}{\boldsymbol{f}}\right)^{\frac{1}{1+\gamma}}=I N \cdots \ldots \ldots \ldots(3) \\
& \boldsymbol{\phi}=\phi_{0}\left(\frac{S}{\boldsymbol{f}}\right)^{\frac{\gamma}{1+\gamma}}=\phi \times 10^{4} \ldots \ldots \ldots(4)
\end{aligned}
$$

ここで $A_{0}$ は基準電気装荷， $\phi_{0}$ は基準磁気装荷， $I$ は 1 脚 の実効值電流， $N$ は巻数， $\phi$ は最大磁束である。

\section{3. 高周波変圧器における装荷統計}

(3)，(4)式における比容量 $\mathrm{S} / \boldsymbol{f}$ と電気装荷 $\boldsymbol{A}$ および磁気装 荷 $\phi$ 関係が実際にどのようになっているかを知る為に は, 高周波変圧器の実機による統計調查を行う必要がある。
表 1 高周波変圧器の仕様

\begin{tabular}{|c|c|}
\hline 容量 $k V A(\mathrm{P}=2)$ & $0.54,1.08,2.16,3.24,5.4,10.8$ \\
\hline 周波数 $f[\mathrm{kHz}]$ & 20 \\
\hline 一次側実効値電圧 $E_{1}[\mathrm{~V}]$ & 216 \\
\hline 二次側実効値電圧 $E_{2}[\mathrm{~V}]$ & 216 \\
\hline デューティー比 $D$ & 0.46 \\
\hline
\end{tabular}

表 2 高周波変圧器の鉄心の形状および材料

\begin{tabular}{|c|c|}
\hline Family & Cut C Core \\
\hline Material & $10 J N E X 900$ \\
\hline Vendor & JFEスチール株式会社 \\
\hline
\end{tabular}
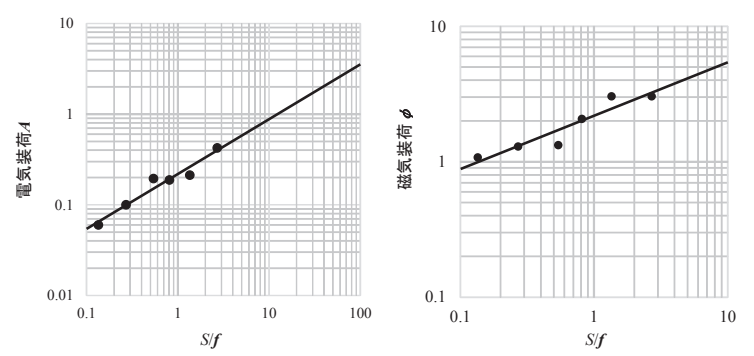

図 1 装荷統計結果

本研究では, フルブリッジコンバータ用高周波変圧器を用 いて装荷統計を行った。装荷統計に用いる高周波変圧器の 仕様を表 1 に, 高周波変圧器の鉄心の形状および材料を表 2 に示す。表 1 および表 2 の高周波変圧器より算出した装荷 統計結果を図 1 に示す。図 1 より, 電気装荷 $\boldsymbol{A}$, 磁気装荷 $\boldsymbol{\phi}$ は比容量 $S / \boldsymbol{f}$ に対して両対数上で微増加傾向を示すことは明 らかである。

したがって(3), (4)式から比容量 $\mathrm{S} / \boldsymbol{f}$ が与えられれば, 電 気装荷 $\boldsymbol{A}$ および磁気装荷 $\boldsymbol{\phi}$ が求まる。その結果, 巻数や鉄 心の断面積等が順次求まり, 変圧器設計が可能となる。

\section{5. まとめ}

本稿では，フルブリッジコンバータ用高周波変圧器を用 いて電気装荷 $\boldsymbol{A}$, 磁気装荷 $\boldsymbol{\phi}$ の装荷統計を行った。実機にお ける高周波変圧器において, 両対数上で電気装荷 $\boldsymbol{A}$, 磁気装 荷 $\boldsymbol{\phi}$ 共に比容量 $\mathrm{S} / \boldsymbol{f}$ に対して微増加傾向が現れることを確認 した。今後は表皮効果, 近接効果の検討を行うと共に, 高 周波変圧器の設計およびDC-DCコンバータに装填した場合 の特性試験を行う予定である。

$$
\text { 文献 }
$$

[1] 竹内寿太郎 :「大学課程 電機設計学」改訂 2 版第 21 刷発行, オーム社, 2012 年 